\title{
Bidirectional air-sea exchange and accumulation of POPs (PAHs, PCBs, OCPs and PBDEs) in the nocturnal marine boundary layer
}

\author{
Gerhard Lammel $^{1,2}$, Franz X. Meixner ${ }^{3}$, Branislav Vrana ${ }^{1}$, Christos I. Efstathiou ${ }^{1}$, Jiři Kohoutek ${ }^{1}$, Petr Kukučka ${ }^{1}$, \\ Marie D. Mulder ${ }^{1}$, Petra Přibylová ${ }^{1}$, Roman Prokeš ${ }^{1}$, Tatsiana P. Rusina ${ }^{1}$, Guo-Zheng Song ${ }^{3}$, and Manolis Tsapakis ${ }^{4}$ \\ ${ }^{1}$ Masaryk University, Research Centre for Toxic Compounds in the Environment, Brno, Czech Republic \\ ${ }^{2}$ Max Planck Institute for Chemistry, Multiphase Chemistry Dept., Mainz, Germany \\ ${ }^{3}$ Max Planck Institute for Chemistry, Biogeochemistry Dept., Mainz, Germany \\ ${ }^{4}$ Hellenic Centre for Marine Research, Institute of Oceanography, Gournes, Greece \\ Correspondence to: Gerhard Lammel (lammel@ recetox.muni.cz)
}

Received: 13 November 2015 - Published in Atmos. Chem. Phys. Discuss.: 1 February 2016

Revised: 3 May 2016 - Accepted: 9 May 2016 - Published: 25 May 2016

\begin{abstract}
As a consequence of long-range transported pollution, air-sea exchange can become a major source of persistent organic pollutants in remote marine environments. The vertical gradients in the air were quantified for 14 species, i.e. four parent polycyclic aromatic hydrocarbons (PAHs), three polychlorinated biphenyls (PCBs), three organochlorine pesticides (OCPs) and two polybrominated diphenylethers (PBDEs) in the gas-phase at a remote coastal site in the southern Aegean Sea in summer. Most vertical gradients were positive $(\Delta c / \Delta z>0)$, indicating downward (net depositional) flux. Significant upward (net volatilisational) fluxes were found for three PAHs, mostly during daytime, and for two OCPs, mostly during night-time, as well as for one PCB and one PBDE during part of the measurements. While phenanthrene was deposited, fluoranthene (FLT) and pyrene (PYR) seem to undergo flux oscillation, hereby not following a day-night cycle. Box modelling confirms that volatilisation from the sea surface has significantly contributed to the night-time maxima of OCPs. Fluxes were quantified based on eddy covariance. Deposition fluxes ranged from -28.5 to $+1.8 \mu \mathrm{g} \mathrm{m}^{-2} \mathrm{day}^{-1}$ for PAHs and -3.4 to $+0.9 \mu \mathrm{g} \mathrm{m}^{-2} \mathrm{day}^{-1}$ for halogenated compounds. Dry particle deposition of FLT and PYR did not contribute significantly to the vertical flux.
\end{abstract}

\section{Introduction}

The marine atmospheric environment is a receptor for persistent organic pollutants (POPs), which are advected from primary and secondary sources on land. This is a concern as these substance bioaccumulate along marine food chains (e.g. Lipiatou and Saliot, 1991; Borgå et al., 2001). Primary sources do not exist in the marine environment, except for polycyclic aromatic hydrocarbons (PAHs; from ship engines). Long-range transport from urban and industrial sources on land are the predominant sources of PAHs and polychlorinated biphenyls (PCBs) in the global oceans (Atlas and Giam, 1986) and in the Mediterranean (Mandalakis et al., 2005; Tsapakis and Stephanou, 2005; Tsapakis et al., 2006; Iacovidou et al., 2009; Mulder et al., 2015).

However, the sea surface itself can turn into a secondary source of POPs provided concentrations build up in surface waters, fed by riverine or atmospheric deposition input. Such studies are still rare. Revolatilisation was observed for hexachlorocyclohexane $(\mathrm{HCH})$ and PAHs, not only in coastal waters (Lohmann et al., 2011), but also in the open sea (Jantunen and Bidleman, 1995; Lakaschus et al., 2002), including the Mediterranean (Castro-Jiménez et al., 2012; Mulder et al., 2014). After long-term accumulation of declining emissions (even after phase-out), a reversal of air-sea exchange may result at some point, as indicated by global modelling for organochlorine pesticides (OCPs; Stemmler and Lammel, 2009). The seasonality of ongoing emissions on the other hand may trigger a seasonal reversal of air-sea exchange, as 
indicated for retene, a PAH emitted from biomass burning in the Mediterranean (summer maximum; Mulder et al., 2014). Similarly, PAHs emitted in fossil fuel combustion in residential heating (winter maximum) may revolatilise seasonally from the sea surface in receptor areas.

The direction of diffusive air-surface exchange flux of organics can be identified by comparing the fugacities and can be quantified based on the Whitman two-film model (Bidleman and McConnell, 1995; Schwarzenbach et al., 2003) or micrometeorological techniques. The latter have so far only rarely been used to quantify air-water (Perlinger et al., 2005; Rowe and Perlinger, 2012; Sandy et al., 2012; Wong et al., 2012) or air-soil (Parmele et al., 1972; Majewski et al., 1993; Kurt-Karakus et al., 2006) gas exchange fluxes.

We studied the vertical fluxes of POPs at sea-surface level with a gradient method at a remote coastal site in the eastern Mediterranean. The measurements were done in the context of a coordinated multi-site campaign on POP cycling in the region (Lammel et al., 2015). The POP concentration in surface seawater was determined too, such that the direction of air-sea exchange could be addressed by a second method.

\subsection{Site and sampling}

The site selected for atmospheric measurements was Selles Beach on the northern coast of Crete, $35.2^{\circ} \mathrm{N} / 25.4^{\circ} \mathrm{E}$, very close $(4 \mathrm{~km})$ to the Finokalia observatory. This is a remote site, some $70 \mathrm{~km}$ east of major anthropogenic emissions (Iraklion, a city of 100000 inhabitants with airport and industries; Mihalopoulos et al., 1997; Kouvarakis et al., 2000). The Mediterranean region includes urban and industrial areas and is adjacent to source regions (i.e. western, central and eastern Europe). Exposure of the study area to long-range transported pollution from central and eastern Europe is highest in summer (Lelieveld et al., 2002).

Organic substances were collected during 3-13 July in the gaseous and particulate atmospheric phases using lowvolume samplers $\left(F \approx 2.3 \mathrm{~m}^{3} \mathrm{~h}^{-1}\right.$, Leckel LVS, $\mathrm{PM}_{10}$ inlet) equipped with quartz fibre filters (QFF, Whatman QMA $47 \mathrm{~mm}$, baked at $320^{\circ} \mathrm{C}$ prior to usage) and two polyurethane foam (PUF) plugs (Molitan, density $0.030 \mathrm{~g} \mathrm{~cm}^{-3}, 5.5 \mathrm{~cm} \mathrm{di-}$ ameter, total depth $10 \mathrm{~cm}$, cleaned by extraction in acetone and dichloromethane, $8 \mathrm{~h}$ each) in series. Two of these samplers collected gases and particles at different heights (inlets at $z_{1}=1.05$ and $z_{2}=2.8 \mathrm{~m}$ ), about $0.5 \mathrm{~m}$ apart in the horizontal. According to the Monin-Obukhov similarity theory of turbulent transport in the surface layer (see Sect. S1.3 in the Supplement), vertical concentration profiles are expected to be logarithmic, while - due to the vertically non-linear behaviour of the eddy diffusivity - the resulting vertical flux is per definitionem constant. For a given surface source (sink) of gases or particles, corresponding negative (positive) vertical concentration gradients $(\partial c / \partial z)$ will be maximal close to the source (sink). Therefore, over aerodynamically smooth surfaces, the lower inlet height should be preferably in the order of a few tenths of a metre, while the distance to the upper inlet height should be maximised to yield large (and consequently statistically significant) vertical concentration differences. However, the choice for the upper inlet height is limited by the horizontal extension of the so-called "fetch", i.e. the upwind surface homogeneity (in terms of orography, structure and vegetation), which should be at least $100 \times z_{2}$ (e.g. Foken, 2008). In the case of our study, the choice of the lower inlet height $\left(z_{1}=1.05 \mathrm{~m}\right)$ is just due to the design of the aerosol sampler, which does not allow sampling below $1.05 \mathrm{~m}$ above ground, while the upper inlet height $\left(z_{2}=2.80 \mathrm{~m}\right)$ accounts for the limited surface homogeneity $(200 \mathrm{~m})$ of the Selles Beach site.

Daytime (09:00-20:00 EEDST and night-time (21:0008:00 EEDST) sampling was conducted from 2 July in the evening to 13 July 2012 in the evening. During part of the measurements, from 6 July in the morning to 10 July 2012 in the evening, a third sampler was used to collect replica of gaseous samples (PUF plugs only) at $z_{1}$. For the concentration at $z_{1}, c_{z}$, replica concentrations (mean of two measurements) were used whenever possible. The samplers were placed on a rocky beach. The horizontal distance between the samplers and the water was $\approx 3 \mathrm{~m}$, while the vertical distance between the rock and water surfaces was $0.1-0.3 \mathrm{~m}$, varying due to tide and waves. After exposure, filters and PUFs were packed in aluminium foil and zip-bags, stored and transported in a cool box to the laboratory.

Free dissolved contaminants in seawater were sampled using silicone rubber (SR) sheets (Altec, Great Britain) as passive water samplers (PWSs). Quantification of trace organics from PWSs is sensitive and validated (Rusina et al., 2010a). Uncertainties in results obtained by application of partitionbased passive samplers are believed to range around a factor of 2, depending on the level of experience of the laboratory (Allan et al., 2009). Different aspects of uncertainty are discussed in Lohmann et al. (2012). At two localities, at distances of 0.8 and $2.2 \mathrm{~km}$ west of Selles Beach, two SR PWSs were deployed in parallel. Each sampler consisted of six sheets $(55 \times 90 \times 0.5 \mathrm{~mm})$. Before exposure, SR sheets were cleaned by Soxhlet extraction in ethyl acetate ( $96 \mathrm{~h})$, followed by methanol ( $48 \mathrm{~h}$, shaken) and spiked by a mix of 15 performance reference compounds (PRCs; $\mathrm{D}_{10}$-biphenyl and 13 PCB congeners not occurring in the environment) according to the procedure (Booij et al., 2002). Samplers were deployed from 3 July to 2 August 2012 in water mounted on stainless steel wire holders at $1 \mathrm{~m}$ depth using buoys and rope. After exposure, samplers were stored and transported in original vials and brought in a cool box to the laboratory.

Daily mean temperature was $28.2(22.4-34.5){ }^{\circ} \mathrm{C}$ and wind velocity was $4.8(0.6-7.7) \mathrm{m} \mathrm{s}^{-1}$ (hourly data). No precipitation occurred. The meteorological situation is described in the Supplement, Sect. S2.1. 


\subsection{Meteorological parameters and vertical flux calculations}

Boundary layer (BL) depth is needed for interpreting the variation of concentrations in air. BL depth data are taken from simulations of the Lagrangian dispersion model FLEXPART, version 9 (Stohl et al., 1998). These were run in a forward direction and based on analysed wind fields (ECMWF, $0.5^{\circ}$ resolution). The model $\mathrm{BL}$ height is calculated according to Vogelezang and Holtslag (1996) using the critical Richardson number. According to wind direction during sampling, we allocate BL depths at upwind locations well off shore $(70-100 \mathrm{~km})$ or inland $(\approx 20 \mathrm{~km})$ as the relevant BL depth for interpretation of atmospheric concentrations at the coastal site. The mean BL depth during sampling intervals is used.

For characterisation of the local meteorological conditions, continuous measurements (5 min averages) of air temperature, relative humidity, wind speed and wind direction were accomplished by three automatic weather stations (model WMT520; Vaisala, Helsinki, Finland) which have been placed at the beach at distances of $\approx 200 \mathrm{~m} \mathrm{(2)} \mathrm{and}$ $\approx 100 \mathrm{~m}$ inland (1) from the sampling location. For characterisation of the atmospheric surface layer's thermodynamic stratification, vertical profiles of wind speed, wind direction, air temperature and relative humidity were determined by continuous measurements at four levels $(0.34,0.70,1.45$ and $3.00 \mathrm{~m}$ above ground). Data were recorded by 2-D ultrasonic wind sensors (model WMT701; Vaisala, Helsinki, Finland) and aspirated temperature and relative humidity sensors (model MP103A; Rotronic, Bassersdorf, Switzerland) in $10 \mathrm{~s}$ intervals, which were averaged to 30 min means for further data processing. For determining key micrometeorological quantities (e.g. sensible heat flux, friction velocity; see Supplement, Sect. S1.3), fast response measurements of the 3-D wind vector and air temperature have been performed by a 3-D ultrasonic anemometer (CSAT-3, Campbell Scientific Inc., Logan, USA) on a small mast, $4 \mathrm{~m}$ above ground and about $7 \mathrm{~m}$ ESE of the profile mast. Corresponding data were continuously recorded with a sampling frequency of $20 \mathrm{~Hz}$ by a suitable logger (model CR3000; Campbell Scientific Inc., Logan, USA). Key micrometeorological quantities were derived from fast response 3-D wind and air temperature data $(20 \mathrm{~Hz})$ according to the eddy covariance (EC) method; $20 \mathrm{~Hz}$ data were processed by the TK3 algorithm (Mauder and Foken, Department of Micrometeorology, University of Bayreuth, Germany), and the results were averaged every $30 \mathrm{~min}$. Only periods with wind direction between 270 and $40^{\circ}$ (i.e. onshore winds) were considered to calculate vertical fluxes of gaseous organics (more details in the Supplement, Sect. S2.1).

The turbulent vertical gaseous organics flux, $F_{c}$ ( $\mathrm{ng} \mathrm{m}^{-2} \mathrm{~s}^{-1}$ ), has been calculated according to the aerodynamic method as the product of the vertical difference of concentration, $\Delta c_{z}\left(\mathrm{ng} \mathrm{m}^{-3}\right)$ and the turbulent transfer velocity, $v_{\text {tr }}\left(\mathrm{m} \mathrm{s}^{-1}\right)$ :

$F_{c}=-v_{\text {tr }} \Delta c_{z}=-v_{\text {tr }}\left[c\left(z_{2}\right)-c\left(z_{1}\right)\right]$,

where $z_{2}$ and $z_{1}$ are the heights of inlets of gaseous organics' sampling (1.05 and $2.80 \mathrm{~m}$, see Sect. 2.1, above). The transfer velocity is a measure of the vertical turbulent (eddy) diffusivity. As long as the vertical concentration gradient is statistically significant, and the choice of the upper inlet height accounts for the homogeneity of the upwind so-called fetch (see above), the resulting flux, calculated from the transfer velocity and the vertical concentration gradient (see Eq. 1), is the vertical turbulent net flux of the corresponding gas, representative for the fetch area and equal to the overall deposition flux (if $c\left(z_{2}\right)-c\left(z_{1}\right)>0$ ).

Details of the underlying formulation and the calculation scheme are given in the Supplement, Sect. S1.3.

\subsection{Chemical analysis}

For organic analysis all samples were extracted with dichloromethane during $\approx 1 \mathrm{~h}$ in an automatic extractor (Büchi B-811). Surrogate extraction standards $\left(\mathrm{D}_{8}-\right.$ naphthalene, $\mathrm{D}_{10}$-phenanthrene, $\mathrm{D}_{12}$-perylene, PCB30, PCB $185,{ }^{13} \mathrm{C}$ BDEs 28, 47, 99, 100, 153, 154, 183 and 209) were spiked on each PUF and QFF prior to extraction. The volume was reduced after extraction under a gentle nitrogen stream at ambient temperature, and fractionation was achieved on a silica gel column. Samples were analysed using a GC-MS (gas chromatograph coupled with a mass spectrometer) Agilent 7890 coupled to Agilent 7000B with a J\&W Scientific fused silica column DB-5MSUI $(60 \mathrm{~m} \times 0.25 \mathrm{~mm} \times 0.25 \mu \mathrm{m})$ for 2-4-ring PAHs (naphthalene (NAP), acenaphthylene (ACY), acenaphthene (ACE), fluorene (FLN), phenanthrene (PHE), anthracene (ANT), fluoranthene (FLT), pyrene (PYR), benzo(a)anthracene (BAA) and chrysene (CHR)). Terphenyl was used as injection standard. The temperature programme was $80^{\circ} \mathrm{C}$, $15^{\circ} \mathrm{C} \mathrm{min}{ }^{-1}$ to $180^{\circ} \mathrm{C}, 5^{\circ} \mathrm{C} \mathrm{min}{ }^{-1}$ to $310^{\circ} \mathrm{C}$. The injection volume was $1 \mu \mathrm{L}$ in splitless mode at $280^{\circ} \mathrm{C}$, with $\mathrm{He}$ used as a carrier gas at a constant flow of $1.5 \mathrm{~mL} \mathrm{~min}^{-1}$.

A sulphuric acid modified silica gel column was used for the PCB/OCP and PBDE clean-up. Samples were analysed using a GC-MS/MS Agilent 7890 coupled to Agilent 7000B with a SGE HT-8 column $(60 \mathrm{~m} \times 0.25 \mathrm{~mm} \times 0.25 \mu \mathrm{m})$ for $\alpha-\mathrm{HCH}, \beta-\mathrm{HCH}, \gamma-\mathrm{HCH}, \delta-\mathrm{HCH}, o, p^{\prime}-$ and $p, p^{\prime}-$ DDE (dichlorodiphenyldichloroethylene), -DDD and -DDT, penta- and hexachlorobenzene (PeCB, HCB). PCB 121 was used as injection standard for chlorinated substances. The temperature programme was $80^{\circ} \mathrm{C}$ ( $1 \mathrm{~min}$ hold), $40^{\circ} \mathrm{C} \mathrm{min}^{-1}$ to $200^{\circ} \mathrm{C}, 5^{\circ} \mathrm{C} \mathrm{min}^{-1}$ to $305^{\circ} \mathrm{C}$. The injection volume was $3 \mu \mathrm{L}$ in splitless mode at $280^{\circ} \mathrm{C}$, with $\mathrm{He}$ used as a carrier gas at constant flow of $1.5 \mathrm{~mL} \mathrm{~min}^{-1}$.

PBDEs were analysed using GC-HRMS (gas chromatography with high-resolution mass spectrometry) on a Restek RTX-1614 column $(15 \mathrm{~m} \times 0.25 \mathrm{~mm} \times 0.1 \mu \mathrm{m})$. The resolu- 
tion was set to $>10000$ for BDE $28-183$ and $>5000$ for BDE 209. ${ }^{13} \mathrm{C}$ BDEs 77 and 138 were used as injection standards. The MS was operated in electron impact $(+)$ mode at the resolution of $>10000$. The temperature programme was $80^{\circ} \mathrm{C}$ ( 1 min hold $)$, then $20^{\circ} \mathrm{C} \mathrm{min}^{-1}$ to $250^{\circ} \mathrm{C}$, followed by $1.5^{\circ} \mathrm{C} \mathrm{min}{ }^{-1}$ to $260^{\circ} \mathrm{C}$ and $25^{\circ} \mathrm{C} \mathrm{min}^{-1}$ to $320^{\circ} \mathrm{C}(4.5 \mathrm{~min}$ hold). The injection volume was $3 \mu \mathrm{L}$ in splitless mode at $280^{\circ} \mathrm{C}$, with $\mathrm{He}$ used as a carrier gas at constant flow of

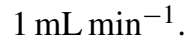

Recovery of native analytes varied between 72 and $102 \%$ for PAHs, between 88 and $103 \%$ for PCBs and between 75 and $98 \%$ for OCPs. The results for PAHs, OCPs and PCBs were not recovery corrected. For PBDEs, isotopic dilution method was used, the average recoveries in the range of 78$128 \%$.

The mean of four field blank values was subtracted from the air sample values. Values below the mean +3 standard deviations of the field blank values were considered to be less than the limit of quantification (LOQ). Field blank values of most analytes in air samples were below the instrument limit of quantification (ILOQ), which corresponded to $6-34 \mathrm{pg} \mathrm{m}^{-3}$ for PAHs, $7-23 \mathrm{pg} \mathrm{m}^{-3}$ for PCB and OCPs and $0.003-0.04 \mathrm{pg} \mathrm{m}^{-3}$ for PBDEs (Supplement, Table S2). Higher LOQs were determined for analytes in gaseous air samples, namely 0.18 and $0.50 \mathrm{ng} \mathrm{m}^{-3}$ for FLN and PHE, and typically $28 \mathrm{pg} \mathrm{m}^{-3}$ for HCB. In the particulate phase a higher LOQ resulted for PHE, i.e. $170 \mathrm{pg} \mathrm{m}^{-3}$. The breakthrough in PUF samples was estimated and, as a consequence, NAP, FLN, HCB and PeCB results are not considered as the sampled air volume (typically $\approx 25 \mathrm{~m}^{3}$ for PUFs) expectedly lead to breakthrough under the prevailing temperatures (Melymuk et al., 2015).

Free dissolved water concentrations of analytes in PWSs were calculated from amounts accumulated in SRs using the exponential uptake model described in Smedes (2007). The required sampling rates were estimated by fitting performance reference compounds dissipation data from sampler to the model described by Booij and Smedes (2010). ILOQ corresponded to $0.5-4.2 \mathrm{pg} \mathrm{L}^{-1}$ for PAHs (but $9 \mathrm{pg} \mathrm{L}^{-1}$ for NAP), $0.05-0.5 \mathrm{pg} \mathrm{L}^{-1}$ for PCB and OCPs and 0.0003$0.037 \mathrm{pg} \mathrm{L}^{-1}$ for PBDEs (Supplement, Table S2). Site specific LOQs were $1-10 \mathrm{pg} \mathrm{L}^{-1}$ for PAHs (but $400 \mathrm{pg} \mathrm{L}^{-1}$ for NAP), $0.1-0.8 \mathrm{pg} \mathrm{L}^{-1}$ for PCB, $0.1-1.4 \mathrm{pg} \mathrm{L}^{-1}$ for OCPs (but $2.8 \mathrm{pg} \mathrm{L}^{-1}$ for $\alpha-\mathrm{HCH}$ ) and $0.01-0.11 \mathrm{pg} \mathrm{L}^{-1}$ for PBDEs (but $0.59 \mathrm{pg} \mathrm{L}^{-1}$ for BDE209).

\subsection{Vertical gradients of trace organics' concentration in air}

Air-sea gas exchange can be studied by determining the vertical concentration gradients of trace gases in air (Doskey et al., 2004; Else et al., 2008).

Three standard deviations of field blank concentrations are considered as the absolute uncertainty of concentration measurements, c, and twice as much as the uncertainty of concen- tration differences, $\Delta c_{z}$. Values of concentrations and vertical concentration differences (gradients) not exceeding these thresholds are considered to be insignificant. This applies to a large fraction of gradients, namely OCP (34 out of 70), PCB (27 out of 44), PBDE (4 out of 5) and PAHs (17 out of 46; Table S3).

\subsection{Air-water fugacity ratio}

The direction of diffusive air-sea gas exchange can be derived from the fugacity ratio calculation, based on the Whitman two-film model (Bidleman and McConnell, 1995). The fugacity ratio, $f_{a} / f_{w}$, is calculated:

$f_{a} / f_{w}=c_{a} R T_{a} /\left(c_{w} H_{T_{w}, \text { salt }}\right)$,

with gas-phase concentration $c_{a}\left(\mathrm{ng} \mathrm{m}^{-3}\right)$, dissolved aqueous concentration $c_{w}\left(\mathrm{ng} \mathrm{m}^{-3}\right)$, universal gas constant $R$ $\left(\mathrm{Pa} \mathrm{m}^{3} \mathrm{~mol}^{-1} \mathrm{~K}^{-1}\right)$, both sea-surface temperature (SST or $\left.T_{w}(\mathrm{~K})\right)$ and salinity corrected Henry's law constant $H_{T_{w} \text {,salt }}$ $\left(\mathrm{Pa} \mathrm{m}^{3} \mathrm{~mol}^{-1}\right.$; see Sect. S1.1 for details) and air temperature $T_{\mathrm{a}}(\mathrm{K}) . T_{\mathrm{a}}$ was adopted from the on-site measurement (see above). $c_{w}$ is derived as the average of the results at two localities, with two replicas each (see above, Sect. 2.1). SST data, measured on the sampling day and in the area, were downloaded from the respective database (see Sect. S1.4 for details). Air and water sampling were not totally in phase: sampling in air occurred over 12 days (2-13 July), while SR exposure occurred over 28 days (3-30 July), i.e. collection was done 10 days after the air sample collection. Consequently, for those substances which are quickly equilibrated (within a few days) in PWS, i.e. HCH and 3-ring PAHs, no simultaneous measurements in air and water were done (see Sect. 2.1). Although the seawater concentrations of $\mathrm{HCH}$ and 3-ring PAHs might have been stable over 28 days, no such evidence exists and we refrain from relating the fugacities. Values $0.3<\mathrm{FR}<3.0$ are conservatively considered to not safely differ from phase equilibrium, as propagating from the uncertainty of the Henry's law constant, $H_{T_{w}}$, salt, and measured concentrations and temperature changes during sampling (e.g. Bruhn et al., 2003; Castro-Jiménez et al., 2012). Substance property data are taken from the literature (Supplement, Table S1). This conservative uncertainty margin is also adopted here, while $f_{a} / f_{w}>3.0$ indicates net deposition and $f_{a} / f_{w}<0.3$ net volatilisation.

\subsection{Non-steady-state 2-box model}

The air-sea mass exchange flux of several OCPs and PAHs are simulated by a non-steady-state zero-dimensional model of intercompartmental mass exchange (Lammel, 2004; Mulder et al., 2014) in order to test the hypothesis that the diurnal variation of contaminant concentrations in air during a period of on-shore advection of one air mass is explained by the combination of volatilisation from the sea surface and atmospheric mixing depth, while advection (long-range trans- 
Table 1. Statistics of (a) concentrations at ground level, $z_{1}=1.05 \mathrm{~m}$ and (b) vertical gradients, $\Delta c_{z}$, over $\Delta z=1.75 \mathrm{~m}$ of gaseous PAHs and halogenated POPs. Mean \pm standard deviation ( $n$, min-max), $\mathrm{ng} \mathrm{m}^{-3}$, except PBDEs: $\mathrm{pg} \mathrm{m}^{-3}$ ). All data are included (exceeding or below uncertainty thresholds). Individual data: see Tables S3, S4. For mean and standard deviations, values $<$ LOQ were replaced by LOQ/2.

\begin{tabular}{|c|c|c|c|}
\hline (a) & all samples & night-time & daytime \\
\hline $\mathrm{ACE}$ & $0.091 \pm 0.021(0.059$ to 0.12$)$ & $0.11 \pm 0.006(5,0.11$ to 0.12$)$ & $0.076 \pm 0.012(5,0.059$ to 0.091$)$ \\
\hline PHE & $1.28 \pm 0.89(0.21$ to 3.54$)$ & $1.00 \pm 0.52(8,0.21$ to 1.46$)$ & $1.47 \pm 1.10(10,0.25$ to 3.54$)$ \\
\hline FLT & $0.35 \pm 0.26(0.044$ to 0.89$)$ & $0.29 \pm 0.24(8,0.046$ to 0.76$)$ & $0.40 \pm 0.29(10,0.044$ to 0.89$)$ \\
\hline PYR & $0.23 \pm 0.20(0.09$ to 0.86$)$ & $0.18 \pm 0.09(6,0.13$ to 0.34$)$ & $0.28 \pm 0.25(8,0.09$ to 0.86$)$ \\
\hline PCB 28 & $0.020 \pm 0.009(0.006$ to 0.037$)$ & $0.021 \pm 0.010(5,0.008$ to 0.033$)$ & $0.020 \pm 0.009(10,0.006$ to 0.037$)$ \\
\hline PCB 52 & $0.012 \pm 0.007(0.003$ to 0.024$)$ & $0.014 \pm 0.008(6,0.003$ to 0.024$)$ & $0.011 \pm 0.005(10,0.003$ to 0.023$)$ \\
\hline PCB101 & $0.008 \pm 0.002(0.005$ to 0.011$)$ & $0.009 \pm 0.002(4,0.006$ to 0.011$)$ & $0.006 \pm 0.001(5,0.005$ to 0.008$)$ \\
\hline$\alpha-\mathrm{HCH}$ & $0.038 \pm 0.021(0.008$ to 0.078$)$ & $0.056 \pm 0.013(6,0.039$ to 0.076$)$ & $0.031 \pm 0.020(10,0.008$ to 0.078$)$ \\
\hline$\gamma-\mathrm{HCH}$ & $0.106 \pm 0.072(0.007$ to 0.245$)$ & $0.136 \pm 0.078(8,0.030$ to 0.245$)$ & $0.089 \pm 0.067(11,0.007$ to 0.242$)$ \\
\hline$p, p^{\prime}$-DDE & $0.007 \pm 0.004(0.003$ to 0.015$)$ & $0.008 \pm 0.003$ (4, 0.006 to 0.012$)$ & $0.007 \pm 0.004(8,0.003$ to 0.015$)$ \\
\hline BDE 47 & $0.327 \pm 0.119(0.20$ to 0.51$)$ & $0.265 \pm 0.046(3,0.228$ to 0.317$)$ & $0.36 \pm 0.14(5,0.20$ to 0.51$)$ \\
\hline BDE 99 & $0.218 \pm 0.062(0.14$ to 0.31$)$ & $0.195 \pm 0.024$ (4, 0.161 to 0.214$)$ & $0.234 \pm 0.077(5,0.137$ to 0.313$)$ \\
\hline (b) & all samples & night-time & daytime \\
\hline ACE & $0.008 \pm 0.047(-0.026$ to 0.10$)$ & $-0.001 \pm 0.027(4,-0.024$ to 0.037$)$ & $0.019 \pm 0.072(3,-0.026$ to 0.10$)$ \\
\hline PHE & $1.24 \pm 2.10(-0.047$ to 7.35$)$ & $1.19 \pm 1.96(4,-0.047$ to 5.55$)$ & $1.29 \pm 2.32(6,0.009$ to 7.35$)$ \\
\hline FLT & $0.19 \pm 0.43(-0.46$ to 0.95$)$ & $0.33 \pm 0.44(6,-0.25$ to 0.95$)$ & $0.073 \pm 0.40(6,-0.46$ to 0.73$)$ \\
\hline PYR & $0.081 \pm 0.21(-0.42$ to 0.45$)$ & $0.18 \pm 0.17(6,0.038$ to 0.45$)$ & $0.004 \pm 0.22(6,-0.42$ to 0.32$)$ \\
\hline PCB 28 & $0.024 \pm 0.046(-0.013$ to 0.155$)$ & $0.013 \pm 0.040(7,-0.011$ to 0.103$)$ & $0.032 \pm 0.050(10,-0.013$ to 0.155$)$ \\
\hline PCB 52 & $0.016 \pm 0.036(-0.011$ to 0.120$)$ & $0.009 \pm 0.036(7,-0.011$ to 0.089$)$ & $0.020 \pm 0.038(10,-0.004$ to 0.120$)$ \\
\hline PCB101 & $0.012 \pm 0.018(-0.005$ to 0.044$)$ & $0.007 \pm 0.019(4,-0.005$ to 0.035$)$ & $0.018 \pm 0.018(4,-0.001$ to 0.044$)$ \\
\hline$\alpha-\mathrm{HCH}$ & $0.079 \pm 0.188(-0.048$ to 0.675$)$ & $0.025 \pm 0.131(5,-0.048$ to 0.258$)$ & $0.107 \pm 0.212(10,-0.019$ to 0.675$)$ \\
\hline$\gamma-\mathrm{HCH}$ & $0.107 \pm 0.273(-0.159$ to 0.890$)$ & $0.018 \pm 0.222(7,-0.159$ to 0.510$)$ & $0.164 \pm 0.297(11,-0.073$ to 0.890$)$ \\
\hline$p, p^{\prime}-\mathrm{DDE}$ & $0.001 \pm 0.005(-0.006$ to 0.009$)$ & $0.002 \pm 0.004(4,-0.001$ to 0.007$)$ & $0.001 \pm 0.006(5,-0.006$ to 0.009$)$ \\
\hline BDE 47 & $-0.229 \pm 0.072(-0.280$ to -0.178$)$ & no data & $-0.229 \pm 0.072(2,-0.280$ to -0.178$)$ \\
\hline BDE 99 & $-0.042 \pm 0.017(-0.059$ to 0.025$)$ & $-0.058(1)$ & $-0.034 \pm 0.014(2,-0.044$ to -0.025$)$ \\
\hline
\end{tabular}

port) is less significant (horizontal homogeneity of air mass; Lammel et al., 2003). This 2-box model predicts concentrations by integration of two coupled ordinary differential equations that solve the mass balances for the two compartments, namely the atmospheric marine BL and seawater surface mixed layer. Processes considered in air are dry (particle) deposition, removal from air by reaction with the hydroxyl radical and air-sea mass exchange flux (dry gaseous deposition), while in seawater export (settling) velocity, deposition flux from air, air-sea mass exchange flux (volatilisation) and degradation (as a first-order process) are considered. Input parameters are listed in the Supplement, Table S3.

\section{Results and discussion}

\subsection{Day-night variation of concentrations in air}

Four PAHs (ACE, PHE, FLT, PYR), three OCPs ( $\alpha$ - and $\gamma$ $\mathrm{HCH}, p, p^{\prime}$-DDE), three PCB congeners (PCB28, -52 and -101) and two PBDE congeners (BDE47 and -99) were quantified in gas-phase samples, while the other species were found $<$ LOQ in all or most samples (Figs. 1a, 2a, Table $1 \mathrm{a}, \mathrm{b})$. This is a consequence of limited air sample vol- ume $\left(\approx 25 \mathrm{~m}^{3}\right)$. PAHs and PBDEs were also found in the particulate phase. The levels observed (Table 1a) are at the lower end of what had been reported from marine, rural and remote sites in the region in the previous $\approx 15$ years, in particular with regard to the chlorinated species (Kamarianos et al., 2002; Mandalakis and Stephanou, 2002; Tsapakis and Stephanou, 2005; Cetin and Odabasi, 2008; Halse et al., 2011; Lammel et al., 2010, 2011; Castro-Jiménez et al., 2012; Berrojalbiz et al., 2014; Mulder et al., 2014, 2015). To our best knowledge, the DDE levels are the lowest reported from the region. This confirms the remote character of the site. Influence from local sources, not expected at this remote site (Iacovidou et al., 2009), is sometimes indicated by an anti-correlation between wind speed and atmospheric concentration. At Selles Beach, dilution by higher wind speed is indeed indicated for one contaminant, ACE (by significant anti-correlation, $p<0.05$ confidence level, $t$ test). This is expected because of its short atmospheric lifetime.

BL depths ranged between 160 and $500 \mathrm{~m}$ during nighttime and 270 and $760 \mathrm{~m}$ during daytime (mean of sampling intervals, i.e. $11 \mathrm{~h}$ ). Day-night variation of contaminants' atmospheric concentrations, often related to mixing and local sources, was not clear: for PAHs the mean ratio 
(a)

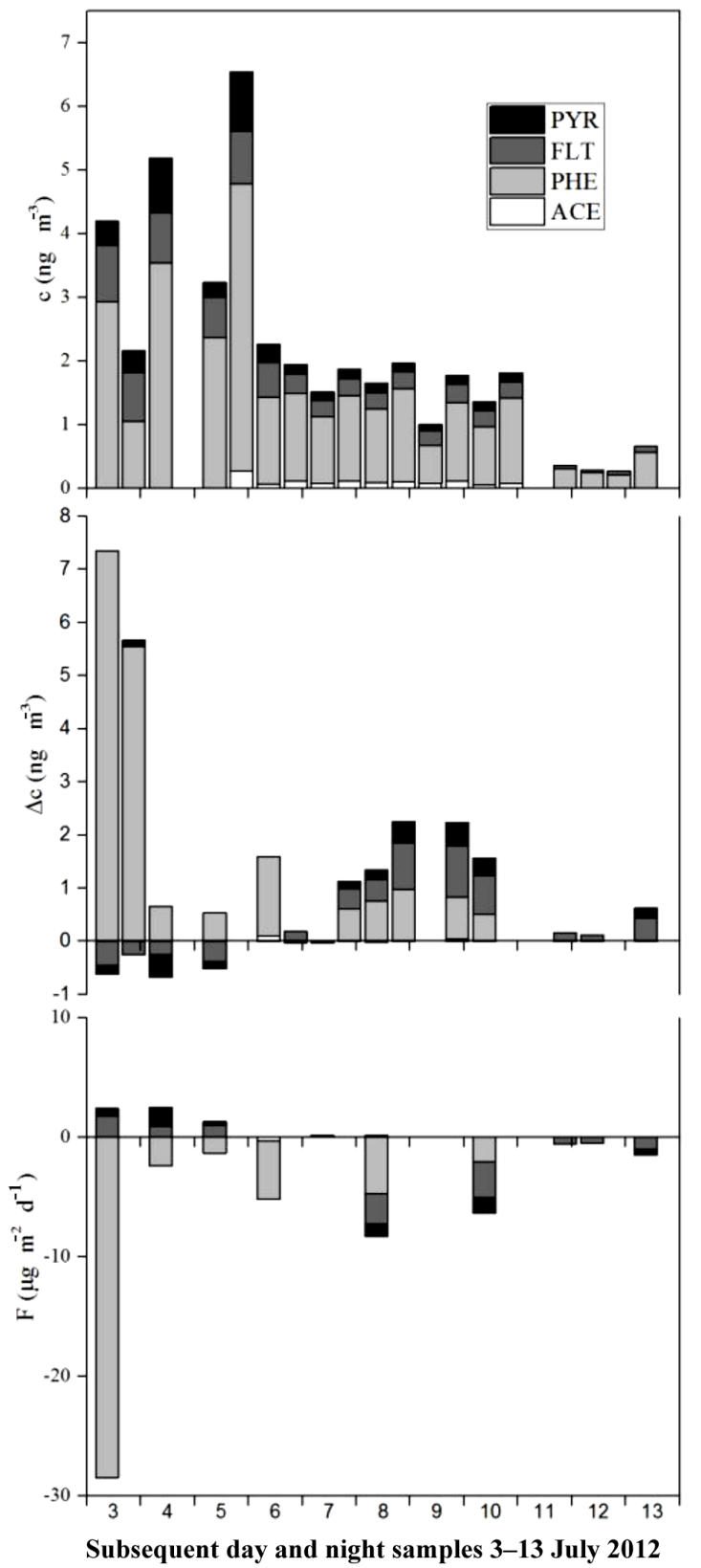

(b)

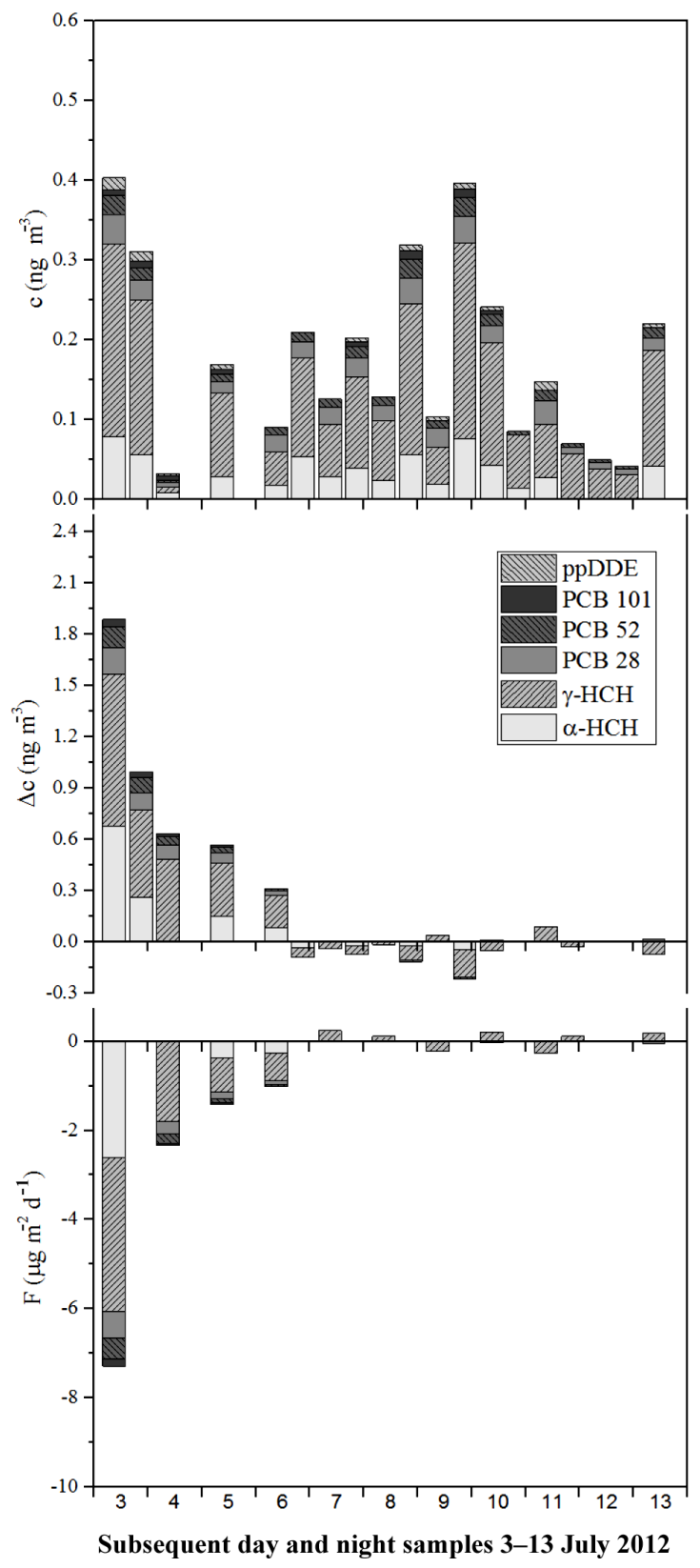

Figure 1. Gaseous (a) PAH and (b) halogenated substances' concentrations at ground level, $z_{1}=1.05 \mathrm{~m}$ (upper), vertical concentration differences, $\Delta c_{z}=c_{z 2}-c_{z 1}$, over $\Delta z=1.75 \mathrm{~m}$ (middle) and vertical fluxes, $F_{c}=-v_{\operatorname{tr}} \Delta c_{z}$ (positive indicates upward, negative indicates downward; lower). Only significant data (exceeding uncertainty thresholds) are shown; gaps represent no data.

of day-night concentrations (gaseous only), $c_{\text {day }} / c_{\text {night }}$, was $0.67(0.54-0.85)$ for ACE, while $c_{\text {day }} / c_{\text {night }}$ ranged wider, at $0.25-3.35$ for PHE, FLT and PYR, with mean values of $c_{\text {day }} / c_{\text {night }}=1.41-1.53$. Also for PBDEs $c_{\text {day }} / c_{\text {night }}>1$ is found (1.20 and 1.37). The low value for ACE can be explained by its short photochemical lifetime (Keyte et al., 2013). $c_{\text {day }} / c_{\text {night }}>1$ was previously observed for PAHs at the same site and explained by temperature-driven volatili- sation from surfaces overcompensating for photochemistry (Lee et al., 1998; Tsapakis and Stephanou, 2007). For chlorinated substances, we find mean $c_{\text {day }} / c_{\text {night }}<1$, namely $0.56-0.66$ for $\mathrm{HCH}$ isomers and $0.68-0.94$ for PCBs and DDE, while the individual values range widely from 0.04 to 4.8. However, there was a clear day-night trend, with mostly night-time maxima of both PAHs (Fig. 1a) and chlorinated species (Fig. 1b) during a period of continuous onshore 
winds, 6-10 July. Apparently, contaminants' concentrations were influenced by BL depth, as indicated by anti-correlation with PAHs and OCPs (except DDE; significant for $\alpha-\mathrm{HCH}$ on the $p<0.05$ confidence level, $t$ test). This results in nighttime accumulation. Diel variation, apart from mixing, is related to advection and air-sea mass exchange and studied in more detail in Sect. 3.2.

\subsection{Diffusive air-sea exchange}

The variation of air concentrations (with night-time maxima) during a period of northerly flow without change of air mass is predicted using the 2-box model (Sect. 2.6). For PCB28, -52 , FLT and BDE47 air concentrations are qualitatively well captured (Fig. 2). These are maintained by dry gaseous deposition alone (PCB52, FLT) or by oscillating fluxes (HCB, PCB28: upward, Fig. 2; PYR: mostly downward, Fig. S4a). The model-predicted fluxes are in good agreement with the observed values (Sect. 3.3, Table S5) except for each daytime sampling interval of FLT and BDE47 (upward fluxes) and for one daytime interval of PCB28 (downward flux; in total four agreements, three disagreements). The modelling results support that (during advection of one air mass) the diel variation of contaminant concentrations in air and, particularly the night-time accumulation, was explained by the combination of volatilisation from the sea surface and atmospheric mixing depth. Volatilisation from the sea surface has significantly contributed to the night-time maxima of $\mathrm{HCB}$ (upward flux, Fig. 2) and PCB28 (Fig. 2), as well as of PYR during one night (Fig. S4a; Table S5). This, to our knowledge, had never been observed before.

$f_{w}$ is derived from the mean concentrations in seawater at two locations (see Supplement, Table S6, for individual data). For the measurement period 2-13 July 2012, the comparison of air-water fugacity ratios (Sect. 2.5) suggests net deposition (prevailing downward fluxes, $f_{a} / f_{w}>3$ ) of gaseous FLT, PYR, BDE47 and -99, net volatilisation (prevailing upward fluxes, $f_{a} / f_{w}<0.3$ ) of gaseous PCB28 and -101 close to phase equilibrium $\left(0.3<f_{a} / f_{w}<3\right)$ for $p, p^{\prime}$ DDE and PCB52 (Table 2). These results are the same as those based on passive air sampling at several locations along the shore at and near Selles Beach (Lammel et al., 2015).

The direction of DDE and PCB fluxes derived from fugacity calculations is consistent with what was indicated by the correlation of air concentrations and BL depth during onshore winds (Supplement, Sect. S2.5).

\subsection{Vertical concentration gradients in air}

PAH vertical gradients mostly indicated deposition, $\Delta c / \Delta z>0$, found in 28 cases (14 during the day, 14 at night), while negative gradients were found in 10 cases (8 during the day, 2 at night). The vertical gradient of PAHs was insignificant in 17 cases. When volatilisation was observed (3-5 July for FLT and PYR, 6-9 July for ACE)
Table 2. Concentrations in air (gaseous, ground level, $z=1.05 \mathrm{~m}$, if > LOQ for most samples; $\mathrm{ng} \mathrm{m}^{-3}$, except PBDEs: $\mathrm{pg} \mathrm{m}^{-3}$ ) and surface seawater $\left(\mathrm{pg} \mathrm{L}^{-1}\right)$ and fugacity ratios, $f_{a} / f_{w}$.

\begin{tabular}{lrrr}
\hline & $c_{a}$ & $c_{w}$ & $f_{a} / f_{w}$ \\
\hline FLT & 0.35 & 18.2 & 19 \\
PYR & 0.23 & 4.4 & 59 \\
PCB 28 & 0.020 & 4.65 & 0.15 \\
PCB 52 & 0.012 & 0.54 & 0.94 \\
PCB 101 & 0.0076 & 0.84 & 0.34 \\
$p, p^{\prime}$-DDE & 0.0072 & 0.84 & 0.76 \\
BDE 47 & 0.33 & 0.15 & 2600 \\
BDE 99 & 0.22 & 0.038 & 16140 \\
\hline
\end{tabular}

$\Delta c / \Delta z$ tended to be clearly lower during daytime, indicating that volatilisation of PAHs from the sea surface was stronger during daytime. This could be explained by a higher fugacity from seawater, $f_{w}$, which increases with $H_{T_{w}}$, salt (see above, Sect. 2.5), which in turn increases with sea-surface temperature, $T_{w}$. Similarly, for the halogenated substances, significant positive gradients, $\Delta c / \Delta z>0$, indicating deposition were more frequent than significant negative gradients, i.e. 37 cases $(15$ PCBs, 22 OCPs, 30 during the day, 7 in one night only) and 20 cases (2 PCBs, 17 OCPs, 1 PBDE, 5 during the day, 15 at night). For these substance classes, a vertical gradient was insignificant in 65 cases (according to the measurement uncertainties). During at least some nights of the period 6-10 July, night-time maxima of $\mathrm{HCH}$ and PCB52 in air coincided with negative vertical gradients, i.e. emissions from the sea surface. Diel variation of PCB52 air-sea exchange flux direction is well reflected by the model (Fig. S4b). This trend is most significant for the $\mathrm{HCH}$ isomers for which a stronger volatilisation flux from the sea surface is found at night than during daytime $(\Delta c / \Delta z<0)$ or even for deposition during daytime $(\Delta c / \Delta z>0$ on 6 and 9 July). Hence, volatilisation from the sea surface may have contributed to and even have caused the night-time maxima of the atmospheric concentrations of HCH and PCB52 (see above and Table 1a): the diel variation of air temperature was small, i.e. daytime mean was typically $0.5-1.5 \mathrm{~K}$ warmer than night-time mean temperature. Even somewhat lower upward fluxes, $F_{c}$, of $\mathrm{HCH}$ at night than during the day, caused by a slightly lower sea-surface temperature, may have caused $c_{\text {day }} / c_{\text {night }}<1$ in combination with the day-night variation of the BL depth (on average $50 \%$ deeper for daytime sampling periods). PBDE daytime maxima may indicate local volatilisation from soil, which are enhanced during daytime. Again, this is consistent with the positive correlation of air concentrations with BL depth (above). Only one BDE concentration gradient was significant, which was volatilisational and during daytime (Fig. 1b, Table 1b). Fluctuating PCB fluxes are in line with the observation that PCBs were close to phase equilibrium in the Aegean in 2006 (Berrojalbiz et al., 2014). To summarise, average significant 
(a)
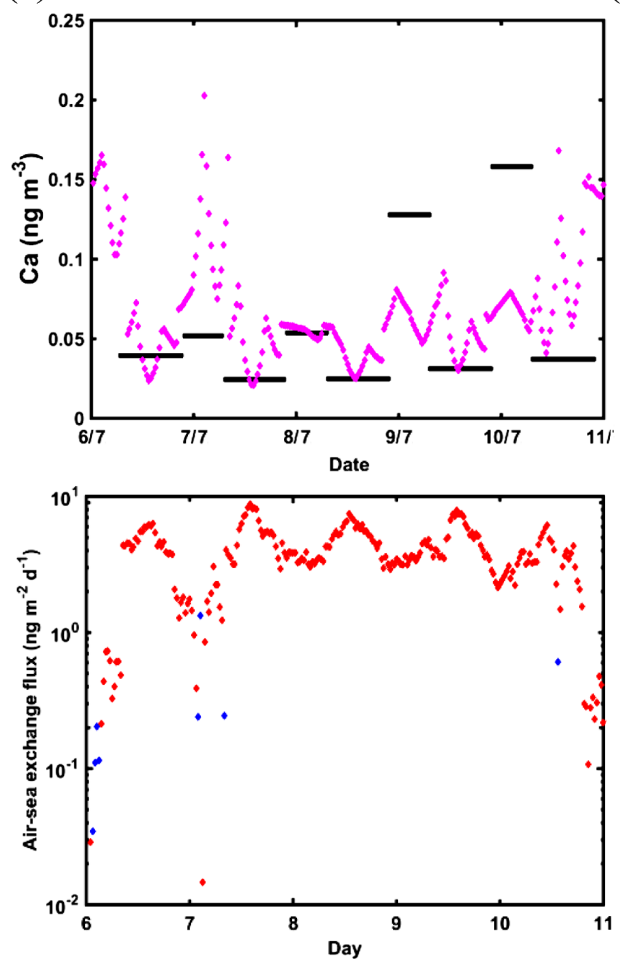

(c)
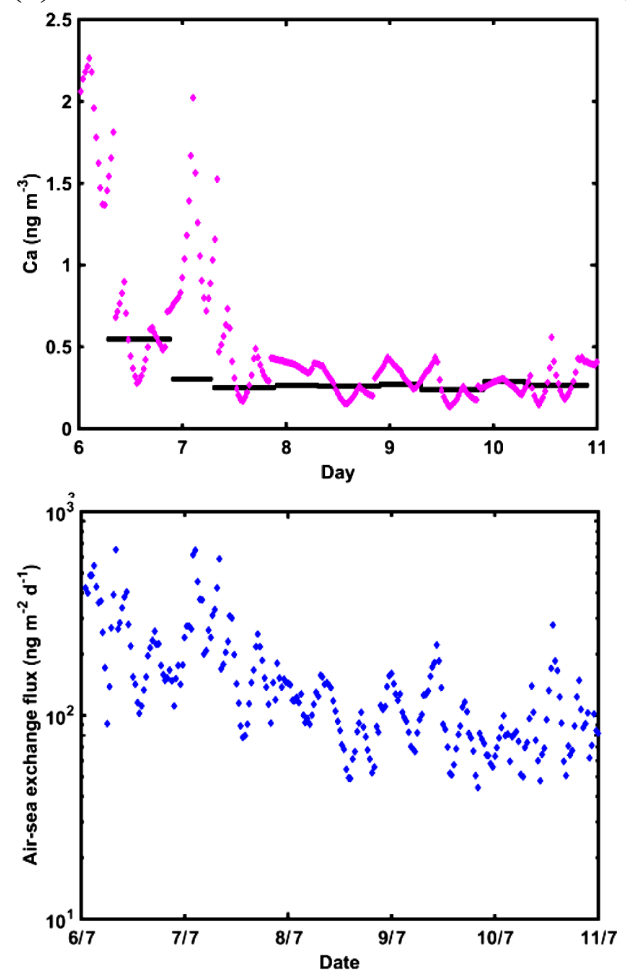

(b)
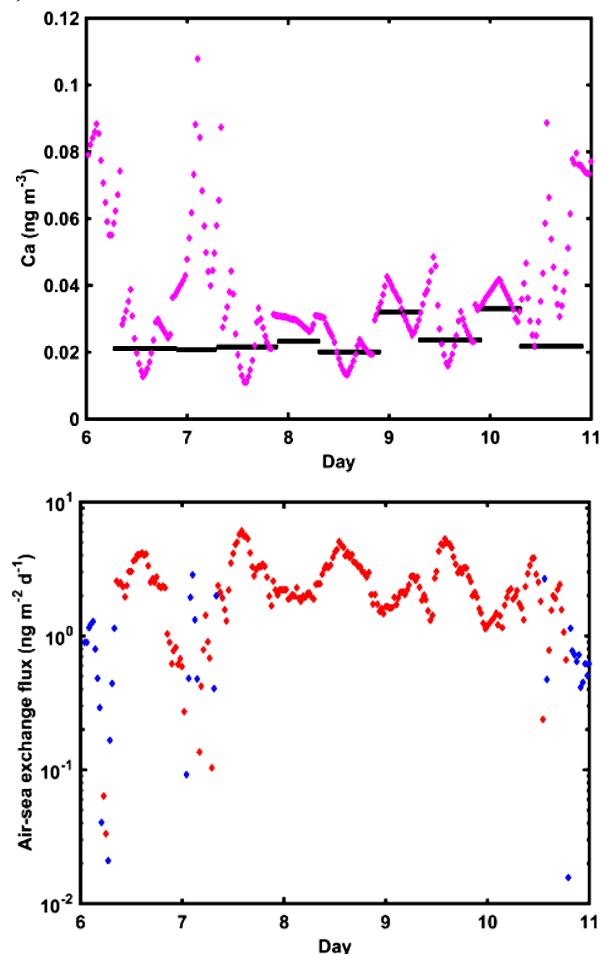

(d)
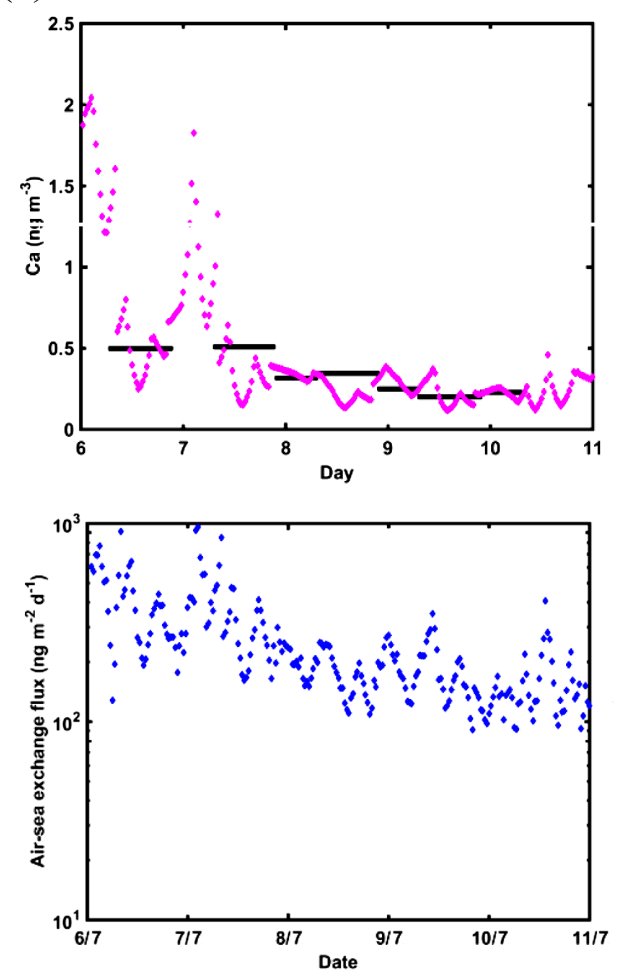

Figure 2. Predicted (pink) and observed (black) concentrations $\left(\mathrm{ng} \mathrm{m}^{-3}\right)$ and predicted diffusive air-sea exchange fluxes, $F_{\mathrm{c}}$, (lower: red upward and blue downward, $\mathrm{ng} \mathrm{m}^{-2}$ day $^{-1}$ ) of selected contaminants, (a) HCB, (b) PCB28, (c) FLT and (d) BDE47 during 6-10 July 2012. 
daytime vertical gradients, $\Delta c / \Delta z$, of all contaminants exceeded average significant night-time gradients, except for FLT and PYR.

The direction of the gradient, hence, of air-sea exchange is found to have changed for ACE, PYR and the HCH isomers on a half-day basis (sequential sampling periods) for FLT in less than two days (Table S4). Changing directions of net air-sea mass exchange had been observed in the region from a ship cruise for OCPs, PCBs and one alkylated PAH, dimethylphenanthrene (Castro-Jiménez et al., 2012; Berrojalbiz et al., 2014) in 2006 and for FLT and PYR in 2010 (Mulder et al., 2014). Fast fluctuation of the direction of air-sea exchange throughout large parts of the year had been found for one alkylated PAH, retene, in the sea region following biomass burning emissions (based on box modelling; Mulder et al., 2014). Earlier, in 2000-2002 air-sea exchange of PAHs was found to be depositional for all members (Tsapakis et al., 2006).

These observations of an increasing number of pollutants attaining phase equilibrium and bidirectional flux may indicate a long-term trend from deposition towards "reversal", i.e. volatilisation of these pollutants in the marine environment of the eastern Mediterranean and more generally of receptor seas regions located in the outflow of regions emitting long-lived semivolatile pollutants, such as most POPs. For substances close to phase equilibrium (attained in a longterm trend), the direction of air-sea exchange may change with a high frequency, as found here. Implicitly, dry deposition is difficult to budget. However, fluctuation may also occur in response to seasonal trends: in summer 2010 FLT and PYR were found close to phase equilibrium in the eastern Mediterranean, while retene (RET) was found mostly volatilisational. A model simulation had revealed that seasonal primary emissions and subsequent deposition of RET (from open fires in the region) are triggering seasonal flux reversal, which over many weeks, however, is fluctuating with a high frequency ( $<24 \mathrm{~h}$; Mulder et al., 2014). Obviously, longer observations are needed to assess the prevailing vertical flux direction. Extrapolation of the observations to annual fluxes is not justified, as day-night fluctuations may be part of a more complex temporal pattern. The seawater surface as a secondary source of pollution should be assessed based on flux measurements during several seasons and over longer time periods.

\subsection{Quantification of vertical fluxes of gaseous contaminants}

Vertical fluxes, $F_{c}$, can be quantified for periods with transfer velocity, $v_{\text {tr }}$, determined, which varied between 3.3 and $8.4 \mathrm{~cm} \mathrm{~s}^{-1}$, on average it was $5.3 \pm 1.9 \mathrm{~cm} \mathrm{~s}^{-1}$. The time coverage of this parameter was $70 \%$; however, satisfying time coverage of sampling intervals was achieved in 14 out of 20 sampling intervals during 11 days (on average $5.5 \mathrm{~cm} \mathrm{~s}^{-1}$ ) and 3 nights (on average $3.5 \mathrm{~cm} \mathrm{~s}^{-1}$ ) (Figs. 1a, 2c, Table S5).
The fluxes of PAHs could be determined based on 8 periods of daytime and 2 periods of night-time sampling. $15 \mathrm{PAH}$ fluxes were downward $\left(F_{c}=-3.6 \pm 7.0 \mu \mathrm{g} \mathrm{m}^{-2} \mathrm{day}^{-1}\right), 8$ upward (ranging $F_{c}=0.8 \pm 0.6 \mu \mathrm{g} \mathrm{m}^{-2}$ day $^{-1}$ ) and 13 insignificant $\left(\left|F_{c}\right|<(0.7 \pm 0.7) \mu \mathrm{g} \mathrm{m}^{-2} \mathrm{day}^{-1}\right)$. Both directions were observed for three species, while the flux of PHE was downward (on average $F_{c}=-7.3 \mu \mathrm{g} \mathrm{m}^{-2}$ day $^{-1}$ ) whenever significant (Table S5a).

$v_{\text {dep }}=-F_{c} / c_{g}$

The above equation corresponded to a mean deposition velocity for gaseous PHE of $v_{\text {dep }}=0.0043 \pm 0.0031 \mathrm{~cm} \mathrm{~s}^{-1}$, still significantly deviating from zero (1 standard deviation criterion, based on measurement at $z_{1}=1.05 \mathrm{~m}$ ). Even 3ring PAHs' deposition is dominated by the particulate phase and a wide range has been reported $\left(0.001-10 \mathrm{~cm} \mathrm{~s}^{-1}\right.$; Zhang et al., 2015), also based on measurements in the region (Tasdemir and Esen, 2009). During the first days of the campaign FLT and PYR were volatilised and later deposited too.

For 11 periods of daytime and 2 of night-time sampling, the fluxes of 8 halogenated substances were downward in 12 cases $\left(F_{c}=-0.58 \pm 0.87 \mu \mathrm{g} \mathrm{m}^{-2} \mathrm{day}^{-1}\right)$ and upward in 6 cases $\left(F_{c}=0.30 \pm 0.31 \mu \mathrm{g} \mathrm{m}^{-2}\right.$ day $^{-1}$; these were $0.11-0.25$ for $\gamma$-hexachlorocyclohexane $(\mathrm{HCH})$ and $0.91 \mu \mathrm{g} \mathrm{m}^{-2} \mathrm{day}^{-1}$ for BDE47) and insignificant in 15 cases $\left(\left|F_{c}\right| 0.19 \pm 0.45 \mu \mathrm{g} \mathrm{m}^{-2} \mathrm{day}^{-1}\right)$ (Table S5b). The fluxes corresponded to mean deposition velocities which were not distinguishable from zero, e.g. $0.020 \pm 0.032 \mathrm{~cm} \mathrm{~s}^{-1}$ for $\alpha$ $\mathrm{HCH}$ and $0.011 \pm 0.015 \mathrm{~cm} \mathrm{~s}^{-1}$ for PCB28 (1 standard deviation criterion).

Air-sea exchange fluxes had been estimated earlier based on measurements in air and seawater in the Aegean Sea as well as from application of the 2-film model in 2001-2002 (Tsapakis et al., 2006) for PAHs and in spring 2006 for PAHs, HCB and PCBs (Castro-Jiménez et al., 2012). Hereby, the flux is calculated proportional to a substance-specific mass transfer coefficient, $k_{\mathrm{ol}}$, strongly dependent on wind velocity and sea-surface temperature (Jurado et al., 2004; Mandalakis et al., 2005). For both PCBs and PAHs, widely varying $k_{\mathrm{ol}}$ values have been estimated (Gigliotti et al., 2002; Mandalakis et al., 2005). The corresponding mean $F_{c}$ (five sampling periods, just one in the case of ACE; Table S5) found in our study in 2012 has the same direction but exceeds the previous findings for PHE (downward) and FLT (downward in 2001-2002, upward in 2006) by more than 1 and 2 orders of magnitude respectively. For PYR the opposite direction (now upward, downward in 2001-2002 and 2006) is found. The flux direction found for the PCBs is unchanged compared to the 2006 measurements, then found close to phase equilibrium (Berrojalbiz et al., 2014). 


\subsection{Particulate phase concentrations and total deposition}

Only PAHs and PBDEs were found to exceed LOQ in the particulate phase. Their day-night variation was minimal (Table S3a, b), on average $c_{\text {day }} / c_{\text {night }}=0.90-1.18$ for particulate PAHs, 1.03 and 1.07 for the PBDEs. This supports the perception that particulate PAH is not attacked by the hydroxyl radical, but "shielded" by the particle matrix (e.g. Zhou et al., 2012). The same had been observed previously at the same site (Tsapakis and Stephanou, 2007). Effective photochemistry can also be excluded for particulate PBDEs for the same reason. While $c_{\text {day }} / c_{\text {night }}=1.20$ and 1.37 for gaseous PBDEs suggests volatilisation from the ground during the day, the absence of $c_{\text {day }} / c_{\text {night }}>1$ for the particulate phase may indicate that the species are not in gas-particle phase equilibrium. This has been pointed out based on previous PBDE measurements in the region (Cetin and Odabasi, 2008). However, the data set discussed here is limited and gas-particle partitioning was not the subject of this study.

Total deposition is the sum of dry and wet deposition, the latter not being significant in the Mediterranean in summer because of small amounts of precipitation. Dry deposition is the sum of particle deposition and diffusive depositional fluxes (part of air-sea exchange, see Sect. 3.2). The dry particle deposition flux, $F_{\mathrm{pdep}}$, can be estimated.

$F_{\mathrm{pdep}}=-v_{\mathrm{dep}} c_{p}$,

with $v_{\text {dep }}$ being determined by particle size and wind speed and $c_{p}$ determined close to the sea surface. Dry particle deposition to the sea surface is most efficient under high wind speeds (Williams, 1982). The mass median diameter of PAHs at remote sites has been mostly found in the submicrometer range (Lipiatou and Saliot, 1991), also during the measurements reported here (own, unpublished data measured simultaneously). For particles of $0.5 \mu \mathrm{m}$, aerodynamic size $v_{\text {dep }} \approx 0.1 \mathrm{~cm} \mathrm{~s}^{-1}$ can be expected for the mean wind velocity at Selles Beach, i.e. $5 \mathrm{~m} \mathrm{~s}^{-1}$ (Slinn and Slinn, 1980). Adopting $v_{\text {dep }}=0.1 \mathrm{~cm} \mathrm{~s}^{-1}$ would suggest $F_{\mathrm{pdep}} \approx-0.023$, -0.016 and $-0.010 \mu \mathrm{g} \mathrm{m}^{-2} \mathrm{day}^{-1}$ for PHE, FLT and PYR $\left(c_{p}=0.26,0.19\right.$ and $0.11 \mathrm{ng} \mathrm{m}^{-3}$ respectively; mean of the same five daytime sampling intervals in the period 3-10 July for which $F_{c}$ was determined, Table S5a). This means that the contribution of $F_{\mathrm{pdep}}$ to dry deposition of PHE was negligible $\left(F_{c} \approx 1000 \times F_{\mathrm{pdep}} ; F_{c}=-26 \mu \mathrm{g} \mathrm{m}^{-2} \mathrm{day}^{-1}\right)$ and $F_{\text {pdep }}$ negligibly compensated for net-volatilisation of FLT and PYR in diffusive air-sea exchange $\left(F_{c}=+0.91\right.$ and $+0.79 \mu \mathrm{g} \mathrm{m}^{-2} \mathrm{day}^{-1}$ for FLT and PYR respectively). The values of $v_{\text {dep }}$ integrated over the entire size spectrum may differ considerably from values of $v_{\text {dep }}$ for MMD (Ruijgrok et al., 1995). Furthermore, the mass median diameter of the semivolatile PAHs, FLT and PYR, might well be larger than $0.5 \mu \mathrm{m}$ as a consequence of redistribution in the aerosol along transport. However, even then, particle deposition is unlikely to have significantly compen- sated for net-volatilisation, as even for particles grown to $1.5 \mu \mathrm{m} F_{\mathrm{pdep}}$ would be higher by not more than a factor of 10 (Slinn and Slinn, 1980). For PHE, FLT and PYR, $F_{\text {pdep }}=-0.021,-0.018$ and $-0.009 \mu \mathrm{g} \mathrm{m}^{-2}$ day $^{-1}$ respectively were determined experimentally at Finokalia Observatory in 2001 (mean of 25 weeks between March and October; Tsapakis et al., 2006). This means that within measurement uncertainties, the particle deposition fluxes found in 2012 are the same as one decade earlier, in both absolute and relative (three PAH members) terms. These fluxes are also in agreement with what was estimated in the Aegean Sea in summer 2006 , namely $F_{\text {pdep }}=-0.010$ to $-0.015 \mu \mathrm{g} \mathrm{m}^{-2} \mathrm{day}^{-1}$ for the same PAHs assuming $v_{\text {dep }} \approx 0.2 \mathrm{~cm} \mathrm{~s}^{-1}$ (Castro-Jiménez et al., 2012).

A similar calculation for the BDEs for one daytime sampling interval $\left(c_{p}=0.16\right.$ and $0.20 \mathrm{ng} \mathrm{m}^{-3}$ for BDE47 and BDE99 respectively; 6 July for which $F_{c}$ was determined, Table S5b) suggests that the contribution of $F_{\mathrm{p} \text { dep }}$ to dry deposition of BDE47 was also negligible $\left(F_{c} \approx 100 \times F_{\mathrm{p} \text { dep }}\right.$; $F_{c}=+3.0 \mu \mathrm{g} \mathrm{m}^{-2} \mathrm{day}^{-1}$ ), while no direct comparison can be made for BDE99 $\left(\left|F_{c}\right| 3.8 \mu \mathrm{g} \mathrm{m}^{-2} \mathrm{day}^{-1}\right.$; Table S5b). Hereby, $v_{\text {dep }}=0.05-0.3 \mathrm{~cm} \mathrm{~s}^{-1}$ was adopted to account for mass median diameters in the range $0.5-1.5$ and mass transfer kinetic limitations for redistribution during long-range transport (Cetin and Odabasi, 2008; Luo et al., 2014; and in agreement with own, unpublished data measured simultaneously in a short distance).

Significant vertical concentration differences in the particulate phase, $\Delta c_{p} / \Delta z>0$ and $\Delta c_{p} / \Delta z<0$, were found. Notably during one daytime and sequential night-time sampling (6-7 July) and during daytime of 9 July, all significant gradients determined for particulate phase contaminants were negative, i.e. higher concentrations at the lower level, $z_{1}$ (PHE and FLT each 1, PYR 2 cases; PBDEs each 1 case; Table S3), while the opposite gradient was found for other nights and days. Marine aerosol contains organic matter (OM), mostly in the accumulation mode, in particular over biologically productive surface waters and under low wind speeds (Gantt et al., 2011; Albert et al., 2012). A considerable part of OM is water insoluble (O'Dowd et al., 2004; Facchini et al., 2008). Hence, the marine aerosol contains traces of POPs, which previously were either in dissolved form or associated with suspended OM. Vertical particle gradients may be sustained by turbulent diffusion (Pryor et al., 2008). While average wind speed was highest during daytime of 9 July, it was average during 6-7 July. No fluxes can be derived from the gradients determined in this study, downwards or upwards.

\section{Conclusions}

The diurnal variation of contaminant concentrations in air at a remote coastal site in the Aegean Sea was explained by the combination of atmospheric mixing depth and volatilisation from the sea surface. Volatilisation from the sea surface 
has significantly contributed to the night-time maxima of (at least) $\mathrm{HCB}, \mathrm{HCH}, \mathrm{PCB} 28, \mathrm{PCB} 52$ and PYR. Apart from long-range transport across the Aegean Sea, local sources were indicated for PBDEs: PBDE cycling was characterised by volatilisation and transport from the island during the day and deposition to the sea surface.

We successfully quantified the diffusive air-sea exchange flux of four 3-4-ring PAHs (in the upper $\mathrm{pg} \mathrm{m}^{-3}$ concentration range), three OCPs, three PCBs and two PBDEs (in the lower $\mathrm{pg} \mathrm{m}^{-3}$ concentration range) at a remote coastal site using a gradient in combination with the eddy covariance technique. Many vertical gradients were insignificant and concentrations of other analytically targeted PAHs, PCBs, OCPs and PBDEs remained $<\mathrm{LOQ}$. More substances could have been included using high-volume sampling, by which the sampled air volume could have been increased by 1 order of magnitude.

Both flux directions were observed (fluctuation) for the OCPs studied, as well as for three PAHs (ACE, FLT, PYR) and one PCB (PCB52), not determined by the day-night cycle. Fluctuation of more substances addressed might have been hidden by gaps in the time series of fluxes (limited by the uncertainties of sampling and analysis) or the time resolution (limited by the sensitivity of the analytical method). Hence, the mean flux direction on one hand and observations during part of the time for the trace substances may differ. For example, volatilisation of BDE47 (observed in one night only) may have been the exception. In general, longer observations and observations across seasons of the flux are needed to assess dry deposition fluxes and the state of airsea exchange of those anthropogenic trace substances which have been approaching phase equilibrium historically (Jantunen and Bidleman, 1995; Stemmler and Lammel, 2009; Berrojalbiz et al., 2014) or seasonally (Mulder et al., 2014).

\section{Information about the Supplement}

Detailed methodological information (substance properties, analytical quality assurance parameters, micrometeorological technique, two-box model) and results (meteorological situation, transfer velocity, atmospheric concentration and flux data).

\section{The Supplement related to this article is available online at doi:10.5194/acp-16-6381-2016-supplement.}

Acknowledgements. We thank Giorgos Kouvarakis and Nikolas Mihalopoulos, University of Crete, Iraklion; Günther Schebeske, MPIC, for on-site support and Dušan Lago, MU, for air mass back-trajectory modelling. This research was supported by the Granting Agency of the Czech Republic (project No. 312334), the Czech Ministry of Education, Youth and
Sports (LO1214 and LM2015051), and the European Union FP7 (No. 262254, ACTRIS).

Edited by: L. Zhang

\section{References}

Albert, M. F. M. A., Schaap, M., Manders, A. M. M., Scannell, C., O'Dowd, C. D., and de Leeuw, G.: Uncertainties in the determination of global sub-micron marine organic matter emissions, Atmos. Environ., 57, 289-300, 2012.

Allan, I. J., Booij, K., Paschke, A., Vrana, B., Mills, G. A., and Greenwood, R.: Field performance of seven passive sampling devices for monitoring of hydrophobic substances, Environ. Sci. Technol., 43, 5383-5390, 2009.

Atlas, E. and Giam, C. S.: Sea-air exchange of high-molecular weight synthetic organic compounds, in: The role of air-sea exchange in geochemical cycles, edited by: Buat-Ménard, P., NATO ASI Ser. Vol. C185, Reidel, Dordrecht, the Netherlands, 295-329, 1986.

Berrojalbiz, N., Castro-Jiménez, J., Mariani, G., Wollgast, J., Hanke, G., and Dachs, J.: Atmospheric occurrence, transport and deposition of polychlorinated biphenyls and hexachlorobenzene in the Mediterranean and Black seas, Atmos. Chem. Phys., 14, 8947-8959, doi:10.5194/acp-14-8947-2014, 2014.

Bidleman, T. F. and McConnell, L. L.: A review of field experiments to determine air-water gas-exchange of persistent organic pollutants, Sci. Total Environ., 159, 101-107, 1995.

Booij, K. and Smedes, F.: An improved method for estimating in situ sampling rates of nonpolar passive samplers, Environ. Sci. Technol., 44, 6789-6794, 2010.

Booij, K., Smedes, F., and van Weerlee, E. M.: Spiking of performance reference compounds in low density polyethylene and silicone passive water samplers, Chemosphere, 46, 1157-1161, 2002.

Borgå, K., Gabrielsen, G. W., and Skaare, J. U.: Biomagnification of organochlorines along a Barents Sea food chain, Environ. Pollut., 113, 187-198, 2001.

Bruhn, R., Lakaschus, S., and McLachlan, M. S.: Air/sea gas exchange of PCBs in the southern Baltic sea, Atmos. Environ., 37, 3445-3454, 2003.

Castro-Jiménez, J., Berrojalbiz, N., Wollgast, J., and Dachs, J.: Polycyclic aromatic hydrocarbons (PAHs) in the Mediterranean Sea: Atmospheric occurrence, deposition and decoupling with settling fluxes in the water column, Environ. Pollut., 166, 40-47, 2012.

Cetin, B. and Odabasi, M.: Atmospheric concentrations and phase partitioning of polybrominated diphenyl ethers (PBDEs) in Izmir, Turkey, Chemosphere, 71, 1067-1078, 2008.

Doskey, P. V., Kotamarthi, V. R., Fukui, Y., Cook, D. R., Breitbeil, F. W., and Wesely, M. L.: Air-surface exchange of peroxyacetyl nitrate at a grassland site, J. Geophys. Res., 109, D10310, doi:10.1029/2004JD004533, 2004.

Else, B. G. T., Papakyriakou, T. N., Granskog, M. A., and Yackel, J. J.: Observations of sea surface $f_{\mathrm{CO}_{2}}$ distributions and estimated air-sea $\mathrm{CO}_{2}$ fluxes in the Hudson Bay region (Canada) during the open water season, J. Geophys. Res., 113, C08026, doi:10.1029/2007JC004389, 2008. 
Facchini, M. C., Rinaldi, M., Decesari, S., Carbone, C., Finessi, E., Mircea, M., Fuzzi, S., Ceburnis, D., Flanagan, R., Nilsson, E. D., de Leeuw, G., Martino, M., Woeltjen, J., and O’Dowd, C. D.: Primary submicron marine aerosol dominated by insoluble organic colloids and aggregates, Geophys. Res. Lett., 35, L17814, doi:10.1029/2008GL034210, 2008.

Foken, T.: Micrometeorology, Springer, Heidelberg, 308 pp., 2008. Gantt, B., Meskhidze, N., Facchini, M. C., Rinaldi, M., Ceburnis, D., and O'Dowd, C. D.: Wind speed dependent size-resolved parameterization for the organic mass fraction of sea spray aerosol, Atmos. Chem. Phys., 11, 8777-8790, doi:10.5194/acp-11-87772011, 2011.

Gigliotti, C. L., Brunciak, P. A., Dachs, J., Glenn, T. R., Nelson, E. D., Totten, L. A., and Eisenreich, S. J.: Air-water exchange of polycyclic aromatic hydrocarbons in the NewYork-NewJersey, USA, harbor estuary, Environ. Toxicol. Chem., 21, 235-244, 2002.

Halse, A. K., Schlabach, M., Eckhardt, S., Sweetman, A., Jones, K. C., and Breivik, K.: Spatial variability of POPs in European background air, Atmos. Chem. Phys., 11, 1549-1564, doi:10.5194/acp-11-1549-2011, 2011.

Iacovidou, E., Mandalakis, M., and Stephanou, E. G.: Occurrence and diurnal variation of polychlorinated biphenyls and polybrominated diphenyl ethers in the background atmosphere of Eastern Mediterranean, Chemosphere, 77, 1161-1167, 2009.

Jantunen, L. M. and Bidleman, T. F.: Reversal of the air-water gasexchange direction of hexachlorocyclohexanes in the Bering and Chukchi Seas: 1993 vs. 1988, Environ. Sci. Technol., 29, 10811089, 1995.

Jurado, E., Jaward, E. M., Lohmann, R., Jones, K. C., and Dachs, J.: Atmospheric dry deposition of POPs to the Atlantic Ocean and inferences for the global oceans, Environ. Sci. Technol., 38, 5505-5513, 2004.

Kamarianos, A., Karamanlis, X., and Galoupi, E.: Pollution of coastal areas of N. Greece by organochlorine pesticides and polychlorinated biphenyls (PCBs), in: Proceedings of the 1st Environmental Conference of Macedonia, 1-4 March 2002, Thessaloniki, Greece, 116-121, 2002.

Keyte, I. J., Harrison, R. M., and Lammel, G.: Chemical reactivity and long-range transport potential of polycyclic aromatic hydrocarbons - a review, Chem. Soc. Rev., 42, 9333-9391, 2013.

Kouvarakis, G., Tsigaridis, K., Kanakidou, M., and Mihalopoulos, N.: Temporal variations of surface regional background ozone over Crete Island in the southeast Mediterranean, J. Geophys. Res., 105, 4399-4407, 2000.

Kurt-Karakus, P. B., Bidleman, T. F., Staebler, R. M., and Jones, K. C.: Measurement of DDT fluxes from a historically treated agricultural soil in Canada, Environ. Sci. Technol., 40, 4578-4585, 2006.

Lakaschus, S., Weber, K., Wania, F., and Schrems, O.: The air-sea equilibrium and time trend of hexachlorocyclohexanes in the Atlantic Ocean between the Arctic and Antarctica, Environ. Sci. Technol., 36, 138-145, 2002.

Lammel, G., Brüggemann, E., Müller, K., and Röhrl, A.: On the horizontal homogeneity of mass-related aerosol properties, Environ. Monit. Assess., 84, 265-273, 2003.

Lammel, G.: Effects of temporally averaging climate parameters on predicted multicompartmental fate of pesticides and POPs, Environ. Pollut., 128, 291-302, 2004.
Lammel, G., Klánová, J., Ilić, P., Kohoutek, J., Gasić, B., Kovacić, I., Lakić, N., and Radić, R.: Polycyclic aromatic hydrocarbons on small spatial and temporal scales - I. Levels and variabilities, Atmos. Environ., 44, 5015-5021, 2010.

Lammel, G., Klánová, J., Erić, L., Ilić, P., Kohoutek, J., and Kovacić, I.: Sources of organochlorine pesticides in an urban Mediterranean environment: Volatilisation from soil, J. Environ. Monitor., 13, 3358-3364, 2011.

Lammel, G., Audy, O., Besis, A., Efstathiou, C., Eleftheriadis, K., Kohoutek, J., Kukučka, P., Mulder, M. D., Přibylová, P., Prokeš, R., Rusina, T., Samara, C., Sofuoglu, A., Sofuoglu, S. C., Tasdemir, Y., Vassilatou, V., Voutsa, D., and Vrana B.: Air and seawater pollution and air-sea exchange of persistent organic pollutants in the Aegean Sea: spatial trends of PAHs, PCBs, OCPs and PBDEs, Environ. Sci. Pollut. Res., 22, 11301-11313, 2015.

Lee, R. G. M., Hung, H., Mackay, D., and Jones, K. C.: Measurement and modeling of the diurnal cycling of atmospheric PCBs and PAHs, Environ. Sci. Technol., 32, 2172-2179, 1998.

Lelieveld, J., Berresheim, H., Borrmann, S., Crutzen, P. J., Dentener, F. J., Fischer, H., Feichter, J., Flatau, P. J., Heland, J., Holzinger, R., Korrmann, R., Lawrence, M. G., Levin, Z., Markowicz, K. M., Mihalopoulos, N., Minikin, A., Ramanathan, V., Reus, M. d., Roelofs, G. J., Scheeren, H. A., Sciare, J., Schlager, H., Schultz, M., Siegmund, P., B. Steil Stephanou, E. G., Stier, P., Traub, M., Warneke, C., Williams, J., and Ziereis, H.: Global air pollution crossroads over the Mediterranean, Science, 298, 794-799, 2002.

Lipiatou, E. and Saliot, A.: Fluxes and transport of anthropogenic and natural polycyclic aromatic-hydrocarbons in the western Mediterranean Sea, Mar. Chem., 32, 51-71, 1991.

Lohmann, R., Dapsis, M., Morgan, E. J., Dekany, E., and Luey, P. J.: Determining air-water exchange spatial and temporal trends of freely dissolved PAHs in an urban estuary using passive polyethylene samplers, Environ. Sci. Technol., 45, 2655-2662, 2011.

Lohmann, R., Booij, K., Smedes, F., and Vrana, B.: Use of passive sampling devices for monitoring and compliance checking of POP concentrations in water, Environ. Sci. Pollut. Res., 19, 1885-1895, 2012.

Luo, P., Ni, H. G., Bao, L. J., Li, S. M., and Zeng, E. Y.: Size distribution of airborne particle-bound polybrominated diphenyl ethers and its implications for dry and wet deposition, Environ. Sci. Technol., 48, 13793-13799, 2014.

Majewski, M. S., Desjardins, R., Rochette, P., Pattey, E., Seiber, J., and Glotfelty, D. E.: Field comparison of an eddy accumulation and an aerodynamic-gradient system for measuring pesticide volatilization fluxes, Environ. Sci. Technol., 27, 121-128, 1993.

Mandalakis, M. and Stephanou, E. G.: Study of atmospheric PCB concentrations over eastern Mediterranean Sea, J. Geophys. Res., 107, 4716, doi:10.1029/2001JD001566, 2002.

Mandalakis, M., Apostolaki, M., Stephanou, E. G., and Stavrakakis, S.: Mass budget and dynamics of polychlorinated biphenyls in the east Mediterranean Sea, Global Biogeochem. Cy., 19, GB3018, doi:10.1029/2004GB002403, 2005.

Melymuk, L., Bohlin-Nizzetto, P., Prokeš, R., Kukučka, P., and Klánová, J.: Sampling artifacts in active air sampling of semivolatile organic contaminants: Comparing theoretical and measured artifacts and evaluating implications for monitoring 
networks, Environ. Pollut., doi:10.1016/j.envpol.2015.12.015, online first, 2015.

Mihalopoulos, N., Stephanou, E., Pilitsidis, S., Kanakidou, M., and Bousquet, P.: Atmospheric aerosol composition above the Eastern Mediterranean region, Tellus B, 49, 314-326, 1997.

Mulder, M. D., Heil, A., Kukucka, P., Klánová, J., Kuta, J., Prokeš, R., Sprovieri, F., and Lammel, G.: Air-sea exchange and gas-particle partitioning of polycyclic aromatic hydrocarbons in the Mediterranean, Atmos. Chem. Phys., 14, 8905-8915, doi:10.5194/acp-14-8905-2014, 2014.

Mulder, M. D., Heil, A., Kukučka, P., Kuta, J., Přibylová, P., Prokeš, R., and Lammel, G.: Long-range atmospheric transport of PAHs, PCBs, OCPs and PBDEs to the central and eastern Mediterranean 2010, Atmos. Environ., 111, 51-59, 2015.

O’Dowd, C. D., Facchini, M. C., Cavalli, F., Ceburnis, D., Mircea, M., Decesari, S., Fuzzi, S., Yoon, Y. J., and Putaud, J. P.: Biogenically driven organic contribution to marine aerosol, Nature, 431, 676-680, 2004.

Parmele, L. H., Lemon, E. R., and Taylor, A. W.: Micrometeorological measurement of pesticide vapor flux from bare soil and corn under field conditions, Water Air Soil Pollut., 1, 433-451, 1972.

Perlinger, J. A., Tobias, D. E., Morrow, P. S., and Doskey, P. V.: Evaluation of novel techniques for measurement of air-water exchange or persistent bioaccumulative toxicants in Lake Superior, Environ. Sci. Technol., 39, 8411-8419, 2005.

Pryor, S., Gallagher, M., Sievering, H., Larsen, S. E., Barthelmie, R. J., Birsan, F., Nemitz, E., Rinne, J., Kulmala, M., Grönholm, T., Taipale, R., and Vesala, T.: A review of measurement and modelling results of particle atmosphere-surface exchange, Tellus B, 60, 42-75, 2008.

Rowe, M. D. and Perlinger, J. A.: Micrometeorological measurement of hexachlorobenzene and polychlorinated biphenyl compound air-water gas exchange in Lake Superior and comparison to model predictions, Atmos. Chem. Phys., 12, 4607-4617, doi:10.5194/acp-12-4607-2012, 2012.

Ruijgrok, W., Davidson, C. I., and Nicholson, K. W.: Dry deposition of particles - implications and recommendations for mapping of deposition over Europe, Tellus B, 47, 587-601, 1995.

Rusina, T., Smedes, F., Kobližková, M., and Klánová, J.: Calibration of silicone rubber passive samplers: experimental and modeled relations between sampling rate and compound properties, Environ. Sci. Technol., 44, 362-367, 2010a.

Rusina, T., Smedes, F., and Klanova, J.: Diffusion coefficients of polychlorinated biphenyls and polycyclic aromatic hydrocarbons in polydimethylsiloxane and low-density polylethylene polymers, J. Appl. Polym. Sci., 116, 1803-1810, 2010 b.

Sandy, A. L., Guo, J., Miskewitz, R. J., McGillis, W. R., and Rodenburg, L. A.: Fluxes of polychlorinated biphenyls volatilizing from the Hudson River, New York measured using micrometeorological approaches, Environ. Sci. Technol., 46, 885-891, 2012.

Schwarzenbach, R. P., Gschwend, P. M., and Imboden, D. M.: Environmental Organic Chemistry, 2nd Edn., Wiley, Hoboken, USA, 2003.
Slinn, S. A. and Slinn, W. G. N.: Predictions for particle deposition on natural waters, Atmos. Environ., 14, 1013-1016, 1980.

Smedes, F.: Monitoring of chlorinated biphenyls and polycyclic aromatic hydrocarbons by passive sampling in concert with deployed mussels, in: Passive sampling techniques in Environmental Monitoring (Comprehensive Analytical Chemistry Vol. 48, edited by: Greenwood, R., Mills, G., and Vrana, B., pp. 407-448, Elsevier, Amsterdam, the Netherlands, 2007.

Stemmler, I. and Lammel, G.: Cycling of DDT in the global oceans 1950-2002: World ocean returns the pollutant, Geophys. Res. Lett., 36, L24602, doi:10.1029/2009GL041340, 2009.

Stohl, A., Hittenberger, M., and Wotawa, G.: Validation of the Lagrangian particle dispersion model FLEXPART against large scale tracer experiments, Atmos. Environ., 32, 4245-4264, 1998.

Tasdemir, Y. and Esen, F.: Dry deposition fluxes and deposition velocities of PAHs at an urban site in Turkey, Atmos. Environ., 41, 1288-1301, 2007.

Tsapakis, M. and Stephanou, E. G.: Polycyclic aromatic hydrocarbons in the atmosphere of the Eastern Mediterranean, Environ. Sci. Technol., 39, 6584-6590, 2005.

Tsapakis, M. and Stephanou, E. G.: Diurnal cycle of PAHs, nitroPAHs and oxy-PAHs in a high oxidation capacity marine background atmosphere, Environ. Sci. Technol., 41, 8011-8017, 2007.

Tsapakis M., Apostolaki, M., Eisenreich, S., and Stephanou, E. G.: Atmospheric deposition and marine sediment fluxes of polycyclic aromatic hydrocarbons in the east Mediterranean Basin, Environ. Sci. Technol., 40, 4922-4927, 2006.

Vogelezang, D. H. P. and Holtslag, A. A. M.: Evaluation and model impacts of alternative boundary-layer height formulations, Bound.-Lay. Meteorol., 81, 245-269, 1996.

Williams, R. M.: A model for the dry deposition of particles to natural water surfaces, Atmos. Environ., 16, 1933-1938, 1982.

Wong, F., Jantunen, L. M., Papakyriakou, T., Staebler, R. M., Stern, G. A., and Bidleman, T. F.: Comparison of micrometeorological and two-film estimates of air-water gas exchange for $\alpha$ hexachlorocyclohexane in the Canadian Archipelago, Environ. Sci. Pollut. R., 19, 1908-1914, 2012.

Zhang, L. M., Cheng, I., Wu, Z. Y., Harner, T., Schuster, J., Charland, J. P., Muir, D., and Parnis, J. M.: Dry deposition of polycyclic aromatic compounds to various land covers in the Athabasca oil sands region, J. Adv. Model. Earth Syst., 7, 13391350, 2015.

Zhou, S., Lee, A. K. Y., McWhinney, R. D., and Abbatt, J. P. D.: Burial effects of organic coatings on the heterogeneous reactivity of particle-borne benzo(a)pyrene (BaP) towards ozone, J. Phys. Chem. A, 116, 7050-7055, 2012. 